\title{
Anti-Corruption Policy Strategies for Nigeria towards National Development: Evidence from Least Corrupt Countries
}

\author{
Adeniran Adetayo Olaniyi \\ Department of Transport Management Technology \\ Federal University of Technology, Akure (FUTA), Ondo State, Nigeria \\ Email: adeniranao@futa.edu.ng
}

\begin{abstract}
Anti-corruption policy strategies in Finland and Singapore were examined, and lessons were drawn for Nigeria. Finland and Singapore were chosen because they are among the least fifth corrupt countries in the world from 2010 to 2017, and they have different norms. Another reason is that the norm in Finland is fairly similar to the norms of Sweden, Denmark, Norway, New Zealand, and Australia which are also among the least corrupt countries in the world, while the norm of Singapore is fairly similar to Hong Kong and Japan which are also among the least corrupt countries in the world. It was revealed that the case of Nigerian society is similar to that of Singaporean society. In Finland, it was observed that anti-corruption measures and institutions are weak as it does not have a separate unit dedicated to investigate or prosecute corruption-related offences, but there is a guiding principle such that anti-corruption measures are integrated into general good governance policy grounded on the rule of law. Also in Singapore, anti-corruption was achieved through anti-corruption policy that has been in existence since the year 1959, although there was a situation of deplorable condition and widespread corrupt practices, but the new government in the late 1950s set up a strategy which resulted that top political leaders set themselves as role models for civil servants and showing zero tolerance for corrupt behaviour. Finally, recommendations were suggested.
\end{abstract}

Keywords: Corruption, Anti-corruption, Development, Nigeria.

Dedication: This paper is dedicated to the $9^{\text {th }}$ National Assembly (I09 Senators headed by Ahmed Lawan, and 360 House of Reps headed by Femi Gbajabiamila) in a moment when crucial laws are meant to be made, most especially towards combating corruption, insecurity, and economic imbalances.

\section{Introduction}

Corruption is widely recognized to be one of the most important obstacles to development in many countries. It is pertinent to note that every citizen in a country deserves quality life which can be achieved when there is a balanced development. According to Akpakpan (1987) and Wilson (2005), development is a process of improvement in the general welfare of the entire society which is usually manifested in the various aspects of the life of society such as a reduction in the level of unemployment; reduction in the extent of personal and regional inequalities; reduction in absolute poverty; rise in real output of goods and services and improvement in techniques of production; improvement in literacy, health services, housing and government services; improvement in the level of social and political consciousness of the people; greater ability to draw on local resources (both human and material) to meet local needs; and reduction in pollution and/or environmental degradation. Hence, balanced development is expected to cut across all the above indicators for development in their correct proportion without deficiency of one or more indicator(s).

The quest for democratic governance is not peculiar to Nigeria as it is a global issue. It is quite saddened to know that good governance, sustainable human development, and democratic governance have not been practically achieved in Nigeria. According to Akinjide (2012), Chief Obafemi Awolowo who was an aristocrat, statesman, Yoruba political leader, Nigerian and African nationalist mentioned that corruption and selfishness go side-by-side. He identified corruption and selfishness as the major factors that have drawl back or brought a decline to the living condition of many Nigerians. Akinjide stated that this condition has recently brought about political instability in the country. In view of this, the obligation for government representatives to provide the conditions that will enable the individuals in the country to receive safe, affordable, and assessable transport infrastructure; quality education; good health; employment, and enjoy dividends of democracy is being questioned. The citizens were disappointed in government administrations at all levels because the government elects have proven not to have risen above corruption and selfishness, and cannot control their instinctive urges to defeat what Awolowo called the 'tyranny of 
the flesh'(Adeniran, 2016). In the recent ranking by Transparency International (2017), Nigeria is ranked I36th in the world. This implies that Nigeria is among the most corrupt countries in the World.

The United Nation Convention against corruption states that corruption undermines democratic institutions, retards economic development and contributes to government instability. Corruption attacks the foundation of democratic institutions by distorting electoral processes, perverting the rule of law, and creating bureaucratic quagmires whose only reason for exis tence is the soliciting of bribes. Apart from corruption among the government elects, corruption has eaten deep into the nukes of all parastatals most especially public institutions and seems difficult to flush out. In view of this, there is a need for anti-corruption policy strategy to combat corruption in the entire Nigerian system. This study, therefore, examines the anti-corruption policy strategies in Finland and Singapore so that lessons can be drawn to strengthen anti-corruption policy strategy in Nigeria and achieve overall national development.

Finland and Singapore are chosen because they are among the least fifth corrupt countries in the world from 2010 to 2017, and they have different norms. Another reason is that Finland's norm is fairly similar to the norms of Sweden, Denmark, Norway, New Zealand, and Australia which are among the least corrupt countries in the world, while Singapore's norm is fairly similar to Hong Kong and Japan which are also among the least corrupt countries in the world.

\section{Conceptual Clarification 2.I Corruption}

It is quite obvious that the definition of corruption differs widely as what might be considered corruption in one country, might be considered as an acceptable practice in another country. The definition of corruption has been in existence earlier than I967, and since then the definition has changed over time and have branched apart from each other having confusion and contentions. Joseph (1967) defines corruption as the behavior, which deviates from the formal duties of a public role because of private considerations (personal, family, and clique) or violates rules against the exercise of certain types of private regarding the influence. According to Kofele (2006), corruption can be defined as an act of requesting, offering, giving or accepting directly or indirectly a bribe or any other undue advantage or the prospect thereof, which distorts the proper performance of any duty or behavior required of the recipient of the bribe, the undue advantage of the prospect thereof.

According to Anti-corruption Policy in Norway (2010), everybody would probably agree that bribes, extortion and the practice of demanding sexual favors in a change of services, are highly unethical acts that must be termed as corruption. According to Transparency International, corruption is the abuse of entrusted power for private gain. Corruption occurs in many forms such as bribery (when someone improperly provides goods or services against some form of improper compensation); kickback (a form of bribery, where someone involved in a purchasing process is getting a reward from the supplier for placing an order of goods or services); embezzlement (theft of resources for own use); evidence destruction (irregular destruction, removal or abuse of records); extortion (the act of obtaining something by force, threats or undue demands); favoritism (the unfair favoring of one person or a group at the expense of others including nepotism which is favoritism shown to relatives); knowingly omitting to report corrupt acts (deliberately omitting or refusing to report or act upon reports of any such irregular or dishonest conduct); maladministration (also referred to as financial misconduct in handling or reporting of money, financial transactions or other assets). The definition of corruption according to Transparency International was adopted in this study as it seems to be elaborate.

\subsection{Impacts of Corruption on National Development: Evidence from other Countries}

Many studies have identified that corruption is a global phenomenon. Although statistics on corruption are often questionable, the data suggest that corruption accounts for a significant proportion of economic activity (Ashok, 20I2). Examples are in Kenya, public expenditures noted by the controller and auditor general in I997 amounted to7.6 percent of GDP; in Latvia a recent World Bank survey found that more than 40 percent of households and enterprises agreed that corruption is a natural part of our lives and helps solve many problems; in Tanzania, service delivery survey data suggest that bribes paid to officials in the police, courts, tax services, and land offices amounted to 62 percent of official public expenditures (Ashok, 20I2). According to Tapales (200I), in the Philippines, the Commission on Audit estimates that $\$ 4$ billion is diverted annually because of public sector corruption. A 2004 World Bank study of the ramifications of corruption for service delivery concludes that an improvement of one standard deviation in the corruption index leads to a 29 percent decrease in infant mortality rates, a 52 percent increase in satisfaction among recipients of public health care, and a 30-60 percent increase in public satisfaction stemming from improved road conditions. Studies also show that corruption slows growth, impair capital accumulation, and reduce the effectiveness of development aid, and increases income inequality and poverty (Tapales, 200I; Ashok, 2012; Adeniran, 2018). Corruption slows GDP growth and adversely affects capital accumulation, public infrastructure, and health services. It lowers the quality of education and reduces the effectiveness of development aid and increases income inequality and poverty (Gupta, Hamid, and Erwin, 2000). 
Not surprisingly, there has been a growing global movement to condemn corrupt practices which is a movement that has resulted in the removal of some national leaders. In addition, many governments and development agencies have devoted substantial resources and energy to fighting corruption in recent years. Despite these efforts, however, it is not clear that the incidence of corruption has declined perceptibly, especially in highly corrupt countries. Bribery is often the most visible manifestation of public sector corruption; it harms the reputation of and erodes trust in many countries.

The huge amount of money was earmarked in the national budget to combat terrorism in Nigeria. In 20I I, 20I2, 2013, 20I4, and 2015, the total expenditures earmarked for security in approved budgets were about $\$ 920$, 924 , $\$ 923$, 923 , and $\$ 934$ billion respectively (Joshua, 20I5; Adeniran and Owoeye, 2018). These huge funds for security have denied capital projects in education, health, agriculture, transportation and other significant sectors that needed more attention (Adeniran and Owoeye, 2018). Despite the huge funds pumped into combating terrorism, the rate of terrorist acts in Nigeria seems increasing since the year 20II. It is obvious that corruption is quite evident in the disbursement of security funds as not all the security funds allocated to combating terrorism are used, some were diverted for personal use.

Corruption in Nigeria leads to promotion and not prison as it is very difficult to catch the so-called big sharks. Corruption in Nigeria has wings, not wheels. As the nation grows, the corrupt practices also grow to invent new methods of cheating the public, most especially the masses or citizens that fall in the low social strata. Political, bureaucratic, corporate and individual corruptions in Nigeria are great concerns. According to Ashok, (2012), over the years, several reasons have been cited by various scholars regarding the sustained existence of corrupt practices leading among them is its nexus with political corruption, lack of accountability and low regulatory controls. Others have suggested a rigid bureaucracy with an exclusivist process of decision making in an overly centralized government.

In Nigeria, corruption has a moral (ethical), legal, and social dilemmas. The moral or ethical dilemmas form the basis of frustrations and consternation amongst all people across societies. A scenario of moral and legal standpoint is an example of Nigerian Police officers that collect bribe from a driver of a stolen vehicle trying to drive the vehicle to a point of resale. The moral perspective this action would be justified, however, at the time, the law forbid vehicle theft. In this case, an illegal action was moral in most regards. The bribe created the breach for the moral act to occur, which likely would not have been the case. Arguably, to reach this end without the bribe would be even more moral. The bribe acted as the tipping mechanism for global moral action that was illegal in the country.

\subsection{Dynamics of corruption}

According to Ashok (2012), corruption is not manifested in one single form but it typically takes at least four broad forms:

- Petty, administrative, or bureaucratic corruption

- Many corrupt acts are isolated transactions by individual public officials who abuse their office by demanding bribes and kickbacks, diverting public funds, or awarding favors in return for personal considerations. Such acts are often referred to as petty corruption, even though, in the aggregate, a substantial amount of public resources may be involved.

- Grand corruption

- This is the form of corruption whereby theft or misuse of vast amounts of public resources by state officials, usually members or people associated with the political or administrative elite. This form of corruption is what majority of the citizen point at because of the huge amount involved.

- State or regulatory capture and influence peddling

- State capture is the collusion by private actors with public officials or politicians for their mutual, private benefit. In this form of corruption, the private sector captures the state legislative, executive, and judicial apparatus for its own purposes. State capture coexists with the conventional (and opposite) view of corruption, in which public officials extort or otherwise exploit the private sector for private ends.

- Patronage, paternalism, clientelism, and being a team player

- This form of corruption occurs when officials use their official position to provide assistance to clients or colleagues with the same geographic, ethnic, or cultural origin so that they receive preferential treatment in their dealings with the public sector, including public sector employment.

- It is important to note that all the listed dynamics of corruption persist in Nigeria, that is why it is difficult to tackle corruption in the Nigerian system. Hence, there is a need for anti-corruption strategies.

\subsection{Overview of the Anti-corruption Strategy in Nigeria}

There are indications that the Nigerian government has been curbing corruption for a long time, which lead the Federal Government of Nigeria to set up anti-corruption strategies. These strategies or mechanism has been employed to curb corrupt practices in Nigeria. These strategies are classified into:

- Institutional model; 
- Legislative model; and

- Dual system approach (Nwobashi and Anthony, 2017; Gashinbaki, 2017; Adeniran, 2018; Adeniran, 2019).

- Institutional model started in 1977 with the object of a gage declaration by the then Head of State, Gen. Olusegun Obasanjo; then followed ethical revolution of President Shagari in 1981; War Against Indiscipline by Gen. Buhari in 1984; National Orientation Movement by Gen. Babangida in 1986; Mass Mobilization for Social Justice by Gen. Babangida in 1987; War Against Indiscipline and Corruption by Abacha; the Independent Corrupt Practices and Other Related Offenses Commission (ICPC) in 2000; the Economic and Financial Crime Commission in 2002 by President Obasanjo (Nwobashi and Anthony, 2017; Adeniran, 2018; Adeniran, 2019).

For the legislative model, Anti-corruption legislations have been codified in several relevant sections of the Criminal Code and the Penal Code Ordinance. Also, available is the Miscellaneous Offenses Act of 1985. One surprising thing is that anticorruption legislations have not fundamentally and substantially changed except the old laws are always like old wine in a new container which attracts slight modifications and new agencies assigned to handle it (Gashinbaki, 2017; Adeniran, 2018).

The following legislation is in place and geared towards the fight against corruption and asset recovery in Nigeria.

- Relevant sections of the criminal code and penal code,

- Miscellaneous Offenses Act, I985,

- The National Drug Law Enforcement Agency Act (NDLEA) of 1988,

- Code of Conduct Bureau and Tribunal Act, I990,

- Banks and other financial Institutions Act, I99I (amended in 2002),

- Money Laundering Act of 1995 (amended in 2002 \& 2004),

- Foreign Exchange Act of I995,

- Failed Bank (Recover Debts) and Financial Malpractices in Banks Act of I994 (amended in 1999),

- Advance Fee Fraud (known as 419) and other Related Offenses Act of 1995 (Nwobashi and Anthony, 2017; Adeniran, 2018). The dual system approach of anti-corruption involves the interface of government institutions/agencies with civil societies/pressure groups and individuals. A coherent relationship between the systems is expected to contribute maximally towards curbing corruption practices in Nigeria. Even though there are no exact statistics on the number of civil society groups in Nigeria, they play a pivotal role in the fight against corruption even though the synergy between the civil society and government agencies is lacking in Nigeria (Nwobashi and Anthony, 2017; Adeniran, 2019). Recently, in a bid to bulk corruption trend as a result of the inefficiencies of civil society and government agencies, Nigeria's ministry of finance recently decided to try a new approach by empowering the citizens to report corruption-related offenses (Whistle Blowing Policy). The hope was that Whistle Blowing Policy would provide established agencies like the EFCC with actionable tips to track and recover stolen government funds (Yemi, 2017). Yemi further state that the policy seems to be working as there were various recovering as stated by Nigeria's Minister of Information, Lai Mohammed. Adeniran (2019) states that despite the plausible results recorded with Whistle Blowing Policy, it is pathetic to note that the efficiency of policy as at present is not clear; also it seems as if the policy is not sustainable because it lacks proper monitoring.

\section{Methodology}

From the survey conducted by Transparency International (2017), it was revealed that Finland is rated third least corrupt country and Singapore is rated sixth least corrupt country in the world; the anti-corruption strategies adopted in these two countries were examined and the lessons derived were recommended for Nigeria.

\section{I Anti-corruption strategy in Finland}

Finnish society is democratic and egalitarian. It was one of the first countries in the world to grant all men and women the right to vote and stand for office. In addition, the standard of living is high with fairly even income distribution. This means that the level of wages in both the public and the private sectors can be termed reasonable, leading to the emergence of a fairly large middle class. These background factors also include an effective and inclusive system of education. Such factors suggest that the Finnish public tend to have a relatively good capacity to understand, exercise and safeguard their rights (Joutsen and Keränen, 2009; Ari-Veikko, 2014).

An important element of Finnish public administration is the impartiality and integrity of civil servants. A special manifestation of such thinking is that an official may not participate in the taking of a decision which may benefit or, alternatively, harm his or her interests or those of another person with whom he or she has a dependent relationship. In such cases, the public official must withdraw from consideration of the matter. From a procedural point of view, the Finnish system is based on what is known as the referendary system, which is actually an old pillar of public administration. Referendary is an official responsible for preparing official matters for a decision-making body. It is also worth emphasizing that the system is 
based on collective and collegiate decision-making, which tends to diminish the likelihood of corruption. An important dimension of all such administrative work is publicity and transparency (Joutsen and Keränen, 2009; Ari-Veikko, 2014).

As Finnish culture and the administrative system support a clean government in various ways, the law enforcement and court system are not the major instances in the big picture of combating corruption. Yet, as in any society, they have their own critical role to play. Finland is an interesting case of anti-corruption policy in the sense that by international standards its anticorruption measures and institutions are weak. It does not have a separate unit dedicated to the investigation or prosecution of corruption-related offenses. This reflects the fact that the guiding principle for anti-corruption work is that corruption is not perceived as an isolated phenomenon, and is therefore not deemed to require separate legal provisions or separate supervisory bodies, nor even a separate strategy or action plan. Instead, anti-corruption measures are integrated into general good governance policy grounded on the rule of law (Joutsen and Keränen, 2009; Ari-Veikko, 2014).

\subsection{Anti-corruption strategy in Singapore}

The fact that corruption is not a way of life in Singapore is an indication of the effectiveness of the anti-corruption policy adopted by the People's Action Party (PAP) government after it took office in II th June 1959. The situation was completely different in colonial times. In fact, corruption was a part of the everyday lives of Singaporeans during the colonial period, especially after the Second World War (Quah, I988). Among the first decisive steps towards clean government was the establishment of the Corrupt Practices Investigation Bureau (CPIB) in the early 1950s as the independent anti-corruption agency, which was actually the first of its kind in the world (Quah, 20II). This turn was based on the initiative by the colonial government after a serious corruption case involving the police and the unsatisfactory situation urged special attention. In spite of this, corruption continued to be rife throughout the sectors of public service, law enforcement being the most corrupted one. Such a deplorable condition was due to inadequate legislation, widespread corrupt practices, the inferior position of the poorly educated population in the eyes of the police and civil servants, low salaries of civil servants and problems in recruiting officers for the anti-corruption agency from the Singapore policy force on short secondment (Tan, I999).

The newly-elected PAP government in the late 1950s was determined to eradicate corruption in Singapore in general and in the civil service in particular. Its strategy for dealing with the problem of corruption emphasized the necessity of reducing both the opportunities and the need for corruption. From the beginning, top political leaders set themselves as role models for civil servants, divesting themselves of commercial ties, demonstrating high work ethics, avoiding any behavior that could be construed as an abuse of their office, and showing zero tolerance for corrupt behavior. By personal example, they created a fruitful soil for the atmosphere of honesty and integrity (Tan, 1999). The PAP government relied heavily on the Prevention of Corruption Act (POCA) and the Corrupt Practices Investigation Bureau (CPIB) to spearhead its anti-corruption strategy. The primary aim of the POCA and CPIB was to reduce the opportunities for corruption and to increase the price to be paid for corrupt behavior if detected (Quah, I988).

In the late 1980s, the essential pillars of Singapore's effective anti-corruption policy were in place and started to bear fruit. It was important that the CPIB since its inception investigated and prosecuted many leading politicians and bureaucrats, which was a sign to the whole of society of the determination to eradicate corruption (Quah, 2007). An important part of the PAP strategy was to tackle the root cause of corruption in the civil service. More than anything, this meant the constant improvement of salaries and working conditions. The assumption was that corruption becomes a serious problem in social conditions where the civil servants are generally paid very low salaries and where there is an unequal distribution of wealth. Accordingly, the salaries of Singaporean civil servants are fairly high by Asian standards (Quah, 1988). The same policy was adopted with politicians too. Top politicians have reiterated Prime Minister Lee Kuan Yew's mantra that political leaders should be paid the top salaries that they deserve in order to ensure clean and honest government (Quah, 1988).

\section{Discussion of Findings}

\section{I Discussion of Findings from the Finland and Singapore}

In tackling corruption, Finland and Singapore have succeeded. These two countries have different kinds of success stories as they have different approaches. Finland's approach is seemingly evolutionary by nature, whereas Singapore is more of a revolutionary case. From a context-specific point of view, they provide models for two different policies, which may be useful when considering country-specific approaches to combating corruption. Finland adopts the model of monitoring and incentives policy while Singapore adopts the model of changing the rules of the game policy (Hanna et al., 20I I). These two models can be used to build an ideal anti-corruption policy for Nigeria.

Finland's model is fairly similar to those found in Sweden, Denmark, and Norway on the one hand, and to some extent also countries of the British Commonwealth such as New Zealand and Australia which are among the least corrupt countries in the Western world. Singapore's model resembles Hong Kong and to a lesser extent Japan which represents the Asian developmental state model. Ari-Veikko (2014) designed the table I below which shows the detailed ethics management models derived from the two cases and contexts. 
Table I: Two ethics management models: Finnish versus the Singaporean model.

\begin{tabular}{|c|c|c|}
\hline Features & $\begin{array}{l}\text { The evolutionary culture-based ethics } \\
\text { management model }\end{array}$ & $\begin{array}{l}\text { The revolutionary compliance-based ethics } \\
\text { management model }\end{array}$ \\
\hline Country & Finland & Singapore \\
\hline Background & Welfare and equality (social); welfare & $\begin{array}{l}\text { Development and growth (economic); } \\
\text { Developmentalism }\end{array}$ \\
\hline Democracy & $\begin{array}{l}\text { The democratic system, free press, civil liberties, } \\
\text { multi-party system }\end{array}$ & $\begin{array}{l}\text { Semi-authoritarian system } \text { (soft } \\
\text { authoritarianism), limited freedoms, dominant- } \\
\text { party system }\end{array}$ \\
\hline Role of politics & $\begin{array}{l}\text { Political pluralism; consensual institutional } \\
\text { support for anti-corruption policy }\end{array}$ & $\begin{array}{l}\text { Personalized leadership; leading politicians' } \\
\text { critical role in supporting anti-corruption policy }\end{array}$ \\
\hline $\begin{array}{l}\text { Role of administration } \\
\text { and anti-corruption } \\
\text { agency (ACA) }\end{array}$ & $\begin{array}{l}\text { Clean, transparent administration; no separate } \\
\text { anti-corruption agency }\end{array}$ & $\begin{array}{l}\text { Clean administration; special role of strong anti- } \\
\text { corruption agency }\end{array}$ \\
\hline \begin{tabular}{ll} 
Major & \multicolumn{2}{r}{ structural } \\
support for anti- \\
corruption policy
\end{tabular} & Cultural values and norms & Political leadership and institutional measures \\
\hline $\begin{array}{l}\text { Development of anti- } \\
\text { corruption policy }\end{array}$ & Evolutionary; piecemeal, integrated policy & $\begin{array}{l}\text { Revolutionary; masterminded anti-corruption } \\
\text { policy }\end{array}$ \\
\hline $\begin{array}{lrr}\begin{array}{l}\text { Approach } \\
\text { corruption }\end{array} & \text { to } & \text { anti- } \\
\text { policy }\end{array}$ & $\begin{array}{l}\text { Weak; holistic approach; no specific anti- } \\
\text { corruption policy or legislation }\end{array}$ & $\begin{array}{l}\text { Strong; spearhead approach; anticorruption } \\
\text { policy and anti-corruption law have an important } \\
\text { role }\end{array}$ \\
\hline $\begin{array}{l}\text { Characteristic measures } \\
\text { of anticorruption policy }\end{array}$ & $\begin{array}{l}\text { Lenient measures: ethical and cultural codes and } \\
\text { principles, instructing, internalization of norms } \\
\text { and values. }\end{array}$ & $\begin{array}{l}\text { Tough measures: investigation, compliance, } \\
\text { control, punishment }\end{array}$ \\
\hline
\end{tabular}

Source: Ari-Veikko (2014)

These two cases point to clear fundamental differences in anti-corruption policy: in a semi-authoritarian society like Singapore, strong leadership and an efficient anti-corruption agency are necessary conditions for successful policy and related cultural change. In the Finnish case, the relationship is the reverse: the cultural background facilitates non-corrupt procedures which rely on transparency and democratic values. The case of Nigeria can be likened to Singapore which is a semi-authoritarian society. Hence, implementable anti-corruption policy should be formulated and strong leadership and an efficient anticorruption agency are needed for successful anti-corruption policy.

\subsection{Lessons from Finland}

- In Finland, the level of wages in both the public and the private sectors can be termed reasonable, leading to the emergence of a fairly large middle class.

- Finnish public tends to have a relatively good capacity to understand, exercise and safeguard their rights.

- Finland adopts referendary system of preparing official matters for a decision-making body as it tends to diminish the likelihood of corruption.

- Although anti-corruption measures and institutions in Finland are weak as it does not have a separate unit dedicated to the investigation or prosecution of corruption-related offenses, there is a guiding principle for anti-corruption work. The principle is that corruption is not perceived as an isolated phenomenon, and is therefore not deemed to require separate legal provisions or separate supervisory bodies, nor even a separate strategy or action plan. Instead, anticorruption measures are integrated into general good governance policy grounded on the rule of law.

- Finland adopts the model of monitoring and incentives policy.

\subsection{Lessons from Singapore}

- Singapore achieved effective anti-corruption through anti-corruption policy that has been in existence since the year 1959. Despite the policy, there was a situation of deplorable condition due to inadequate legislation, widespread corrupt practices, the inferior position of the poorly educated population in the eyes of the police and civil servants, low salaries of civil servants. The new government in the late 1950s set up a strategy for dealing with the problem of corruption by emphasized the necessity of reducing both the opportunities and the need for corruption. It was 
recorded that top political leaders set themselves as role models for civil servants, divesting themselves of commercial ties, demonstrating high work ethics, avoiding any behavior that could be construed as an abuse of their office, and showing zero tolerance for corrupt behavior.

- In the year 1980, the policy of 1950 was modified such that new statements were introduced, this led to the investigation and prosecution of many leading politicians and bureaucrats, which was a huge sign to the Singaporean society of the determination to eradicate corruption. This event shows that there was nothing like "immunity" in the policy context.

- Singapore adopts the model of changing the rules of the game policy.

\section{Conclusion and Recommendation}

This study examines the anti-corruption strategies in Finland and Singapore. In Finland, it was observed that anti-corruption measures and institutions are weak as it does not have a separate unit dedicated to investigate or prosecute corruption-related offenses, but there is a guiding principle for the anti-corruption framework. The principle is that corruption is not perceived as an isolated phenomenon, and is therefore not deemed to require separate legal provisions or separate supervisory bodies, nor even a separate strategy or action plan. Instead, anti-corruption measures are integrated into general good governance policy grounded on the rule of law.

In Singapore, anti-corruption was achieved through anti-corruption policy that has been in existence since the year 1959. Despite the policy, there was a situation of deplorable condition due to inadequate legislation, widespread corrupt practices, the inferior position of the poorly educated population in the eyes of the police and civil servants, low salaries of civil servants. The new government in the late 1950s set up a strategy for dealing with the problem of corruption by emphasized the necessity of reducing both the opportunities and the need for corruption. It was recorded that top political leaders set themselves as role models for civil servants, divesting themselves of commercial ties, demonstrating high work ethics, avoiding any behavior that could be construed as an abuse of their office, and showing zero tolerance for corrupt behavior.

From the study, the following recommendations were derived for Nigeria:

- There is a need to establish a unified definition of corruption in the policy context, content, and consequence.

- New laws should be created with severe punishment and efficient monitoring of implementing the new laws.

- Top political leaders in Nigeria should set themselves as role models for civil servants, and deny themselves of commercial ties, demonstrate high work ethics, and avoid any behavior that could be construed as an abuse of their office.

- The model of monitoring and incentives policy should be adopted; also the model of changing rules of game policy should be adopted if needed.

- There is a need to have exact statistics on the number of registered civil society groups in Nigeria so as to strengthen the synergy between civil society and government agencies towards fighting corruption.

- The wages of the public and private sector in Nigeria should be revisited and monitored to close or reduce the wide gap between the rich and the poor.

- There is a need for public awareness of safeguarding human rights in Nigeria.

- Nigeria should adopt a referendary system of preparing official matters for a decision-making body as it will diminish the likelihood of corruption.

- In addition to the institutional model, legislative model, and dual system approach of curbing corruption in Nigeria, anti-corruption measures should be integrated into general good governance policy grounded on the rule of law.

- The immunity placed upon certain offices especially in executives that have handicapped anti-corruption agencies from prosecuting the offenders should be totally removed. The traces of immunity in the anti-corruption policy context should be removed.

\section{References}

Adeniran, A. O. (2016). The Rational Approach of Obafemi Awolowo's Principles in Enhancing Efficient Leadership and Good Governance through Intellectual Enormity. International Policy Review, 2(9):3I-37.

Adeniran, A. O. (2018). Assessment of Federal Governments' Effort on Looted Assets Recovery in Nigeria as a Means of Fighting Corruption and Terrorism. Discovery, 54(276), 453-462.

Adeniran, A. O. (2019). Anti-corruption Strategies for Balanced Development: A Case Study of Economic and Financial Crimes Commission (EFCC) Advanced Journal of Social Science, 5(I), 52-64. DOI: https://doi.org/I0.21467/ajss.5.I.5264

Adeniran, A. O. and Owoeye, A. S. (2018). Logistical Perspective towards Counterterrorism of Boko Haram Insurgency in Nigeria: Lessons and Way-Out. Journal of Industrial Engineering and Safety, I(I), I-I I. DOI: 10.0000/JIES.1000102. 
Akinjide, A. (2012). The Philosophical Import of Obafemi Awolowo's: Theory of Mental Magnitude. Department of Arts Education, Adekunle Ajasin University, 2(2).

Akpakpan, B. E. (1987). Crossroads in Nigerian Development. Port Harcourt: New Generation Publishers.

Ari-Veikko, A. (20I4). Good Governance in Context: Learning from Anti-corruption Policies of Finland and Singapore. Munich Personal RePEc Archive (MPRA). Available online at https://mpra.ub.uni-muenchen.de/67807/ MPRA Paper No. 67807, posted I0. November 2015 17:26 UTC, Accessed on 25 ${ }^{\text {th }}$ May 2018.

Ashok, R. B. (2012). Corruption in Administration with Special Reference to India. Pp. I-25

Gashinbaki, I. B. (2017). Anti-corruption: An evaluation of strategies, and systems in Nigeria.

Gupta, S., Hamid, D., and Erwin, T. (2000). Corruption and the Provision of Health Care and Education Services. Working Paper 00/I 16, International Monetary Fund, Washington, DC.

Hanna, R., Bishop, S., Nadel, S., Scheffler, G. and Durlacher, K. (20II). The Effectiveness of Anti-corruption Policy: What has worked, what hasn't, and what we don't know-a systematic review. EPPI-Centre report 1909. London: EPPI-Centre, University of London, London.

Joseph, S. N. (1967). Corruption and political development: A cost-benefit analysis. The American Political Science Review, $6 I(2): 4 I 9$.

Joutsen, M. and Keränen, J. (2009). Corruption and the Prevention of Corruption in Finland. Ministry of Justice, Helsinki, Finland.

http://www.om.fi/en/Etusivu/Julkaisut/Esitteet/CorruptionandthePreventionofCorruptioninFinland (Accessed 25th May 2018)

Kofele, K. (2006). The International Law of Responsibility for Economic Crimes: Holding State Officials Individually Liable for Acts of Fraudulent Enrichment. Hampshire, England: Ashgate Publishing Ltd.

Nwobashi, H. N. and Anthony, I. (2017). Democratic Governance and the Fight Against Corruption in Nigeria: A Critical Appraisal of Economic and Financial Crime Commission (EFCC) Anti-corruption Strategies under Buhari's administration. Middle-East Joumal of Scientific Research, 25(4): 74I-753. DOI: 10.5829/idosi.mejsr.2017.74I.753.

Tan, A. L. (1999). The Experience of Singapore in Combating Corruption. in R. Stapenhurst and Kpundeh, S. J. (Eds.), Curbing Corruption: Toward a Model for Building National Integrity, EDI Development Studies. World Bank, Washington, D.C., Pp.59-66.

Tapales, P. (200I). An Evaluation of Anti-corruption Programs in the Philippines. World Bank, Operations Evaluation Department. Washington, DC.

Transparency International Corruption Perceptions Index 2017

Quah, J. S. T. (1988). Corruption in Asia with Special Reference to Singapore: Patterns and Consequences. Asian Journal of Public Administration, IO ( I): 80-98.

Quah, J. S. T. (2007). Combating Corruption Singapore-style: Lessons for Other Asian Countries. Maryland Series in Contemporary Asian Studies, (2): I89. The University of Maryland, School of Law, Baltimore, Maryland.

Quah, J. S. T. (20I I). Innovation in Public Governance in Singapore: Solving the Housing Shortage and Curbing Corruption', in A.-V. Anttiroiko, S.J. Bailey and Pekka Valkama (Eds.), Innovative Trends in Public Governance in Asia, IOS Press, Amsterdam, Pp.I2I-I36.

United Nation Development Programme (UNDP) (2007). Governance for Sustainable Human Development. A UNDP Policy Paper.

Wilson, G. (2005). Economic and Social Infrastructure: Provision, Distribution, and Maintenance in Chukuemeka, A. and Nyekachi, A. (eds) Applied Economics in Perspectives. Port Harcourt: ROD Printing and Publishing Company, Chapter 5 (Pp. 93-I28).

Yemi, K. (2017). Nigeria's new corruption whistleblowing policy is helping the government recover looted funds. Retrieved on $23^{\text {rd }}$ December 2017 from http://www.qz.com/9090I4

\section{Copyrights}

Copyright for this article is retained by the author(s), with first publication rights granted to the journal. This is an open-access article distributed under the terms and conditions of the Creative Commons Attribution license (http://creativecommons.org/licenses/by/4.0/). 